\title{
Lipopolysaccharides Do Not Alter Metabolic Disturbances in Hippocampal Slices of Fetal Guinea Pigs after Oxygen-Glucose Deprivation
}

\author{
RICHARD BERGER, YVES GARNIER, DORIS PFEIFFER, AND ARNE JENSEN
}

Department of Obstetrics and Gynecology, Ruhr-Universität Bochum, In der Schornau 23-25, D-44892

Bochum, Germany

\begin{tabular}{|c|c|}
\hline \multicolumn{2}{|c|}{ ABSTRACT } \\
\hline $\begin{array}{l}\text { The aim of the present study was to clarify whether endotox- } \\
\text { ins [lipopolysaccharides (LPS)] have a toxic effect on fetal brain } \\
\text { tissue after cerebral ischemia, while excluding their effect on the } \\
\text { cardiovascular system. Experiments were therefore performed on } \\
\text { hippocampal slices prepared from mature fetal guinea pigs. In } \\
\text { particular, we studied the influence of LPS on nitric oxide } \\
\text { production, energy metabolism, and protein synthesis after oxy- } \\
\text { gen-glucose deprivation (OGD). Incubating hippocampal slices } \\
\text { in LPS ( } 4 \mathrm{mg} / \mathrm{L} \text { ) for as long as } 12 \mathrm{~h} \text { did not alter cGMP tissue } \\
\text { concentrations significantly. However, } 10 \text { min after OGD of } \\
40 \text {-min duration, cGMP tissue concentrations were substantially } \\
\text { increased in relation to controls, and this increase was almost } \\
\text { completely blocked by the application of } 100 \mu \mathrm{M} N^{\omega} \text {-nitro-L- } \\
\text { arginine, indicating that nitric oxide synthase was activated after } \\
\text { OGD in fetal brain tissue. Again, LPS did not have any effect on } \\
\text { cGMP tissue concentrations after OGD. Furthermore, addition of } \\
\text { LPS altered neither protein synthesis nor energy metabolism }\end{array}$ & $\begin{array}{l}\text { measured } 12 \mathrm{~h} \text { after OGD. We therefore conclude that, apart } \\
\text { from their well-known influence on the cardiovascular system, } \\
\text { LPS do not alter metabolic disturbances in hippocampal slices of } \\
\text { fetal guinea pigs } 12 \mathrm{~h} \text { after OGD. A direct toxic effect of LPS on } \\
\text { immature brain tissue within this interval does not therefore seem } \\
\text { to be very likely. However, delayed activation of LPS-sensitive } \\
\text { pathways that may be involved in cell death, or damage limited } \\
\text { to a small subgroup of cells such as oligodendrocyte progenitors, } \\
\text { cannot be fully excluded. (Pediatr Res 48: 531-535, 2000) } \\
\text { Abbreviations } \\
\text { aCSF, artificial cerebrospinal fluid } \\
\text { AEC, adenylate energy charge } \\
\text { OGD, oxygen-glucose-deprivation } \\
\text { LPS, lipopolysaccharides } \\
\text { L-NNA, } N^{\omega} \text {-nitro-L-arginine } \\
\text { NO, nitric oxide }\end{array}$ \\
\hline
\end{tabular}

Hypoxic-ischemic cerebral damage is an important contributor to perinatal mortality and morbidity, including long-term neurologic sequelae in term and preterm fetuses. On the other hand, there is increasing evidence that perinatal brain damage is caused not only by hypoxic-ischemic insults, but also by ascending intrauterine infection before or during birth (1). Infants whose amnion is acutely inflamed are at a much greater risk of developing brain injury than control subjects $(2,3)$. However, it remains unclear whether fetal brain damage is the result of cerebral hypoperfusion caused by circulatory decentralization owing to severe endotoxemia or is caused by a direct effect of endotoxins on cerebral tissue (4). The present study was therefore set up to clarify whether endotoxins (LPS) have a direct toxic effect on fetal brain tissue after cerebral ischemia, while excluding their effects on the cardiovascular system. For this purpose we used the in-vitro system of OGD in hippocam-

Received August 31, 1999; accepted May 5, 2000.

Correspondence: Priv.-Doz. Dr. R. Berger, Universitätsfrauenklinik Bochum, Knappschaftskrankenhaus, In der Schornau 23-25, D-44892 Bochum, Germany.

Supported by Deutsche Forschungsgemeinschaft Be 1688/4-1. pal slices prepared from mature guinea pig fetuses $(5,6)$. In particular, we studied the influence of LPS on NO production, energy metabolism, and protein synthesis after OGD. Prolonged inhibition of protein synthesis after OGD seems to be an especially sensitive early marker of ischemic cell injury (7).

\section{METHODS}

The present study was performed on guinea pigs, a precocious species, at 0.9 gestation (term, $68 \mathrm{~d}$ ). The dams were anesthetized with halothane and decapitated, and fetuses were delivered by cesarean section. The fetal hippocampi were dissected out and cut into 500- $\mu \mathrm{m}$-thick transverse slices. The tissue slices were transferred to an incubation chamber, containing aCSF (standard). To prevent bacterial contamination, $10 \mathrm{mg} / \mathrm{L}$ each of streptomycin and erythromycin were added to the aCSF. Additionally, aCSF was filtered (pore diameter, 0.1 $\mu \mathrm{m}$ ) into sterilized containers, and $\mathrm{CuSO}_{4}$ was added to the incubation chamber reservoir. The aCSF was pumped through the incubation chamber at a rate of $1 \mathrm{~mL} / \mathrm{min}(5,8)$. The aCSF was equilibrated with a gas mixture of oxygen and carbon 
dioxide $\left(95 \% \mathrm{O}_{2} / 5 \% \mathrm{CO}_{2}\right)$, and the incubation temperature was held at $37^{\circ} \mathrm{C}$. After a period of $90 \mathrm{~min}$, during which the tissue was allowed to recover from preparation stress, the glucose concentration of the standard aCSF was lowered from $10 \mathrm{mM}$ to $2 \mathrm{mM}$ for $30 \mathrm{~min}$. This was done to accelerate the breakdown of high-energy phosphates in tissue slices during exposure to $\operatorname{OGD}(5,6)$.

The experimental protocol included a 120 -min preincubation phase $(90 \mathrm{~min}$ in $10 \mathrm{mM}$ glucose and $30 \mathrm{~min}$ in $2 \mathrm{mM}$ glucose aCSF), an ischemic phase (10-40 $\mathrm{min})$, and a recovery phase ( $12 \mathrm{~h}$ starting from the end of OGD). A separate incubation chamber, equilibrated with $95 \% \mathrm{~N}_{2} / 5 \% \mathrm{CO}_{2}$, was used for the induction of OGD. In contrast to the standard aCSF, the ischemic aCSF contained no glucose or HEPES. HEPES was omitted because its buffering capacity can influence the fall in $\mathrm{pH}$ accompanying OGD. Before the tissue slices were transferred to the anoxic incubation chamber, they were washed in aglycemic aCSF to lower the glucose concentrations in the tissue still further. During OGD, the tissue slices were completely submerged in the aCSF. No additional aCSF was pumped through the chamber during this period (flow rate, $0 \mathrm{~mL} / \mathrm{min}$ ). In the postischemic phase, the tissue slices were transferred back to standard aCSF (flow rate, $1 \mathrm{~mL} / \mathrm{min}$ ) and equilibrated with $95 \% \mathrm{O}_{2} / 5 \% \mathrm{CO}_{2}$.

To prove whether the hippocampal slice model has the power to detect effects of LPS on neuronal tissue, we measured tissue concentrations of TNF- $\alpha$ in hippocampal slices incubated for $12 \mathrm{~h}$ in standard aCSF containing $4 \mathrm{mg}$ LPS/L aCSF (Escherichia coli; O127:B8; Sigma Chemical Co., Deisenhofen, Germany). Intraperitoneal injection of LPS at this dosage $(4 \mathrm{mg} / \mathrm{kg}$ body weight) killed newborn guinea pigs $(n=3)$ within $6 \mathrm{~h}$. Moreover, this dosage caused cardiac failure in adult guinea pigs within $4 \mathrm{~h}(8,9)$. At various intervals, six groups (control group, $n=3$; study group, $n=3$ ) consisting of four slices each were sampled. Tissue slices from each group were pooled and homogenized by ultrasonification for $5 \mathrm{~s}$ in $100 \mu \mathrm{L}$ of ice-cold Tris-citrate (pH 7.4), with $10 \mathrm{mM}$ 4-(2-aminoethyl)-benzene sulfonyl fluoride (Sigma Chemical Co.) as described previously (10). The homogenates were centrifuged $\left(12,000 \times \mathrm{g}, 10 \mathrm{~min}, 4^{\circ} \mathrm{C}\right)$, the supernatants were retained, and the pellet was homogenized again. The supernatants from the two extractions were pooled, and aliquots (100 $\mu \mathrm{L}$, approximately $0.5 \mathrm{mg}$ protein/aliquot) were removed for the quantification of TNF- $\alpha$ using a commercially available ELISA (R\&D Systems, Wiesbaden, Germany).

To further elucidate the effects of endotoxins on cellular metabolism, we studied NO production in hippocampal slices incubated in standard aCSF containing $4 \mathrm{mg}$ LPS/L aCSF for $12 \mathrm{~h}$. As a measure of NO production, we determined the tissue concentration of cGMP at various intervals using an RIA (NEN, Bad Homburg, Germany) $(6,11)$. For this purpose, tissue slices were frozen in liquid nitrogen and extracted with perchloric acid. Moreover, we tested whether the activation of NO synthase in immature brain tissue after OGD is altered by LPS. In this set of experiments, hippocampal slices were incubated in aCSF containing LPS ( $4 \mathrm{mg} / \mathrm{L}) 2 \mathrm{~h}$ before, during, and $10 \mathrm{~min}$ after OGD. Ten minutes after OGD, the tissue concentration of cGMP was measured as described above. To confirm that elevated tissue concentrations of cGMP really reflected increased NO production, we simultaneously blocked NO synthase in a portion of the slices with $100 \mu \mathrm{M}$ L-NNA (6).

A further series of experiments was set up to test the effect of LPS on the recovery of energy metabolism and protein synthesis in tissue slices $12 \mathrm{~h}$ after OGD (duration, 20-40 $\mathrm{min})$. For this purpose, a set of hippocampal slices was incubated in aCSF containing LPS (4 mg/L) $2 \mathrm{~h}$ before, during, and $12 \mathrm{~h}$ after OGD.

Tissue slices were frozen in liquid nitrogen for subsequent measurement of tissue concentrations of adenine nucleotides. ATP, ADP, and AMP were measured by HPLC after extraction with perchloric acid (5). The AEC, a measure of the relation of energy consumption to energy production, was estimated from the following formula (12):

$$
\mathrm{AEC}=([\mathrm{ATP}]+0.5[\mathrm{ADP}]) /([\mathrm{ATP}]+[\mathrm{ADP}]+[\mathrm{AMP}])
$$

The protein content of the tissue slices was measured by the method of Lowry et al. (13).

Protein synthesis was assessed from the incorporation rate of ${ }^{14} \mathrm{C}$-leucine into tissue proteins. After $30 \mathrm{~min}$ of incubation in standard aCSF, to which $5 \mu \mathrm{Ci} / \mathrm{mL}$ L- $\left[1-{ }^{14} \mathrm{C}\right]$ leucine (specific activity, $54 \mathrm{mCi} / \mathrm{mmol}$; Amersham Buchler, Braunschweig, Germany) had been added, the tissue slices were homogenized in trichloroacetic acid. The radioactivity of the trichloroacetic acid-precipitated material was then measured by liquid scintillation counting (5).

All data are given as means \pm SD. Except for the experiments on TNF- $\alpha$ concentration, test groups consisted of five tissue slices each. The statistical significance of differences among groups was assessed by a two-way ANOVA, followed by the Scheffé post hoc test. The experimental protocols were approved by the appropriate institutional review committee and met the guidelines of the governmental agency responsible.

\section{RESULTS}

The effect of LPS on TNF- $\alpha$ tissue concentration is shown in Figure 1. During an incubation period of 12 h, TNF- $\alpha$ tissue concentrations did not change in the control group, whereas in the study group LPS caused a significant rise in the tissue concentration of this cytokine. In contrast, incubating hippocampal slices in LPS $(4 \mathrm{mg} / \mathrm{L})$ for as long as $12 \mathrm{~h}$ did not alter NO production as measured by cGMP tissue concentrations (Fig. 2A). However, cGMP concentrations were dramatically altered by inducing OGD in hippocampal slices. Twenty minutes after OGD, cGMP tissue concentrations were significantly increased compared with controls (Fig. 2B), and this increase was almost completely blocked by the application of $100 \mu \mathrm{M}$ L-NNA (Fig. 2C). Again, LPS had no effect on cGMP tissue concentrations even after OGD (Fig. 2B).

As already shown in earlier studies, prolonged OGD in this experimental model leads to disturbances of energy metabolism and protein synthesis during the subsequent recovery phase $(5,6)$. In the same way, a reduction of ATP concentration (Fig. 3A) and protein synthesis (Fig. 3B) in slices of the control group to $36 \%$ and $63 \%$ of initial values, respectively, was observed here in tissue slices after 40 min OGD. Incubat- 


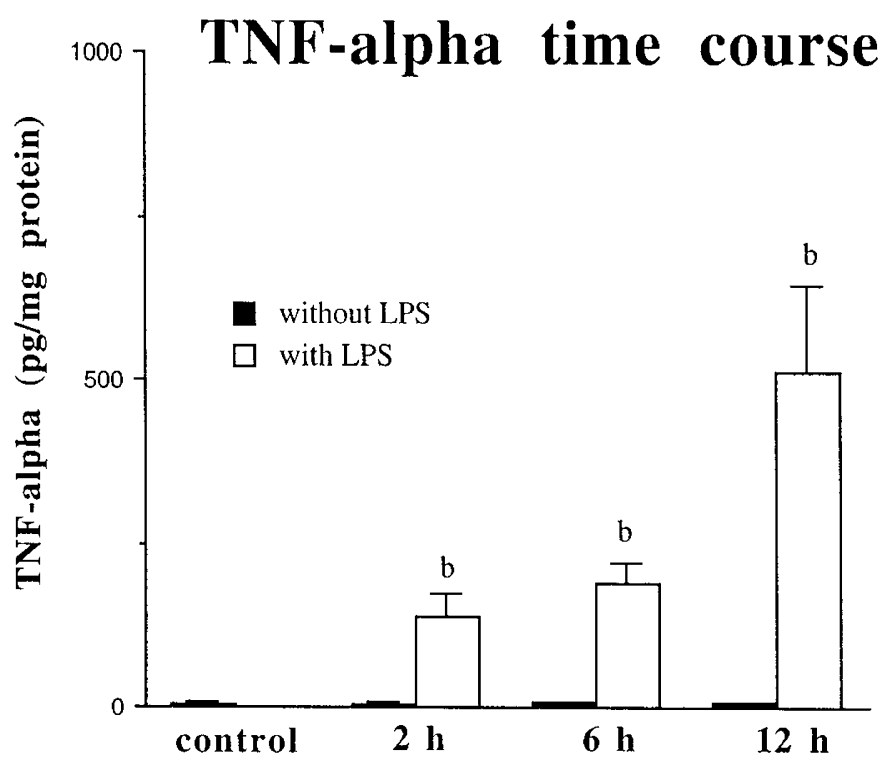

Figure 1. Concentration of TNF- $\alpha$ in hippocampal tissue slices incubated in standard aCSF containing LPS $(4 \mathrm{mg} / \mathrm{L})$ for $12 \mathrm{~h}$. Values are given as mean \pm SD. The statistical significance of differences within groups was assessed by ANOVA and Scheffé post hoc test. b, $p<0.05$ (with LPS $v s$ without LPS).

ing slices in LPS $(4 \mathrm{mg} / \mathrm{L})$ altered neither the postischemic recovery of tissue concentrations of ATP nor the rates of protein synthesis. Similar results were obtained for the total adenylate pool and AEC (Table 1).

\section{DISCUSSION}

Recently various clinical studies have shown that fetuses suffering from intrauterine infection have a higher incidence of cerebral palsy in later life $(1,14)$. However, the exact pathophysiologic mechanisms underlying this observation are still poorly understood. As we know from studies in fetal sheep, endotoxemia may cause circulatory decentralization and thus lead to cerebral hypoperfusion and brain damage (4). Besides this indirect effect on brain tissue, LPS may also have direct toxic effects. To clarify this point, we performed experiments on hippocampal tissue slices $(5,6)$. In this way, any effect of LPS on the microcirculation could be excluded. Using this setup, hippocampal slices of mature guinea pig fetuses remain metabolically intact for periods of up to $12 \mathrm{~h}$, even when the temperature of the bath is set at $37^{\circ} \mathrm{C}$.

As shown in Figure 1, application of LPS to the incubation medium did significantly increase tissue concentrations of TNF- $\alpha$. Thus, the hippocampal slice model seems to be a suitable experimental setup for detecting effects of LPS on fetal neuronal tissue. Furthermore, because TNF- $\alpha$ concentration increased substantially in the hippocampal tissue after application of endotoxins, it is very likely that considerable amounts of LPS penetrated the slices during incubation. This view is supported by in vivo studies in which a significant expression of cytokines in the brain tissue of adult animals was observed after injection of LPS into the cerebral ventricles (15-17). However, application of LPS to the incubation medium did not increase cGMP concentrations in hippocampal slices prepared from fetal guinea pigs, indicating that NO synthase was not
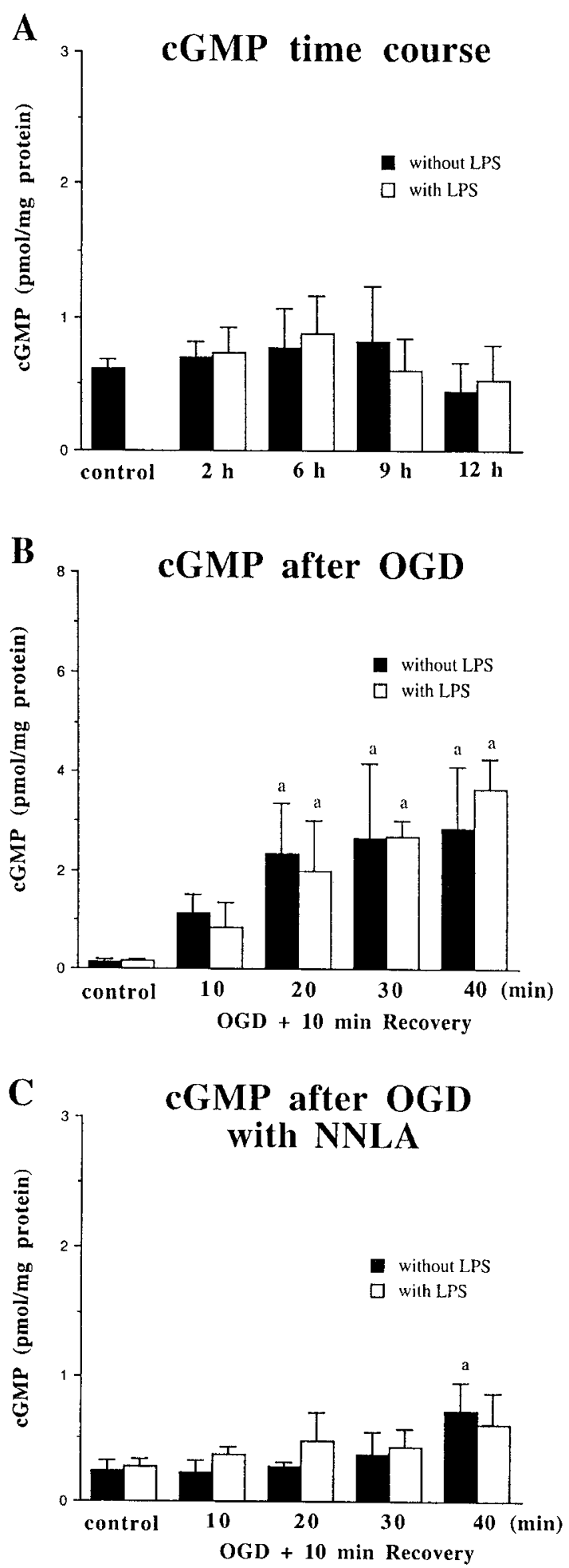

Figure 2. Concentration of cGMP in hippocampal tissue slices after exposure to LPS and OGD. $A$, Time course of concentration of cGMP in hippocampal tissue slices after different periods of incubation in standard aCSF with and without LPS $(4 \mathrm{mg} / \mathrm{L}) . B$, Concentration of cGMP in hippocampal tissue slices after different durations of OGD (10-40 $\mathrm{min})$ and a recovery period of $10 \mathrm{~min}$. A set of these tissue slices was incubated in LPS $(4 \mathrm{mg} / \mathrm{L})$ for $2 \mathrm{~h}$ before, during, and $10 \mathrm{~min}$ after OGD. $C$, In addition to the experimental protocol described in $B$, all slices were incubated in $100 \mu \mathrm{M}$ L-NNA for $30 \mathrm{~min}$ before, during, and $10 \mathrm{~min}$ after OGD. Values are given as mean $\pm \mathrm{SD}$. The statistical significance of differences within and between groups was assessed by ANOVA and the Scheffé post hoc test. a, $p<$ 0.05 (OGD vs controls). Significant differences between groups could not be detected. 


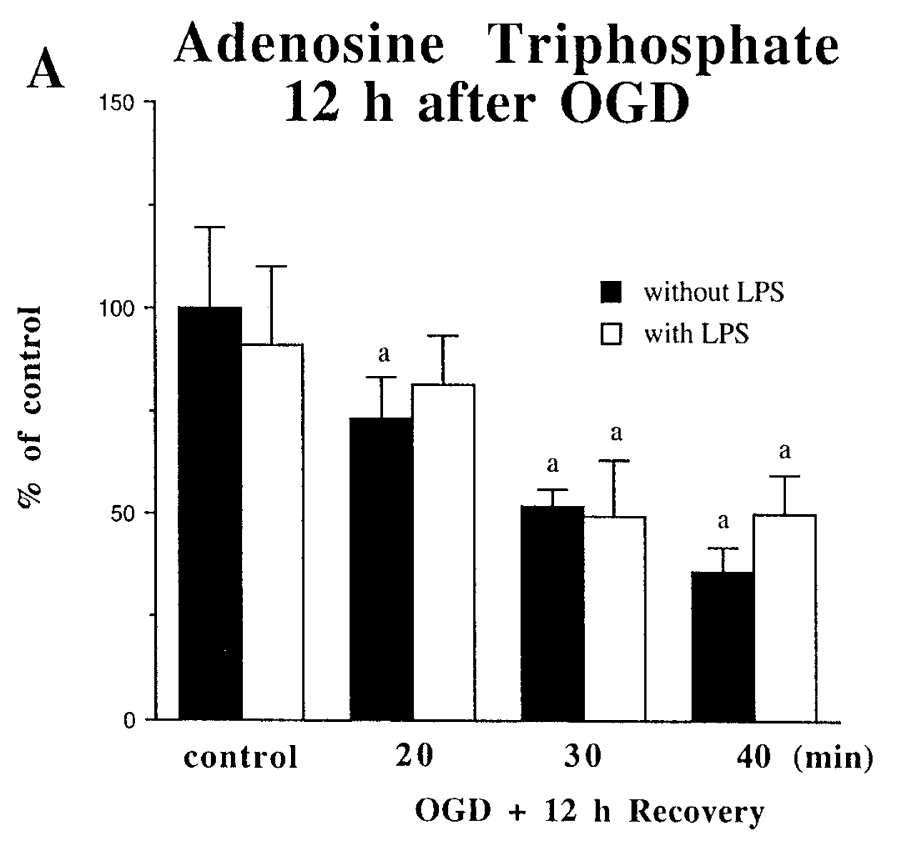

B

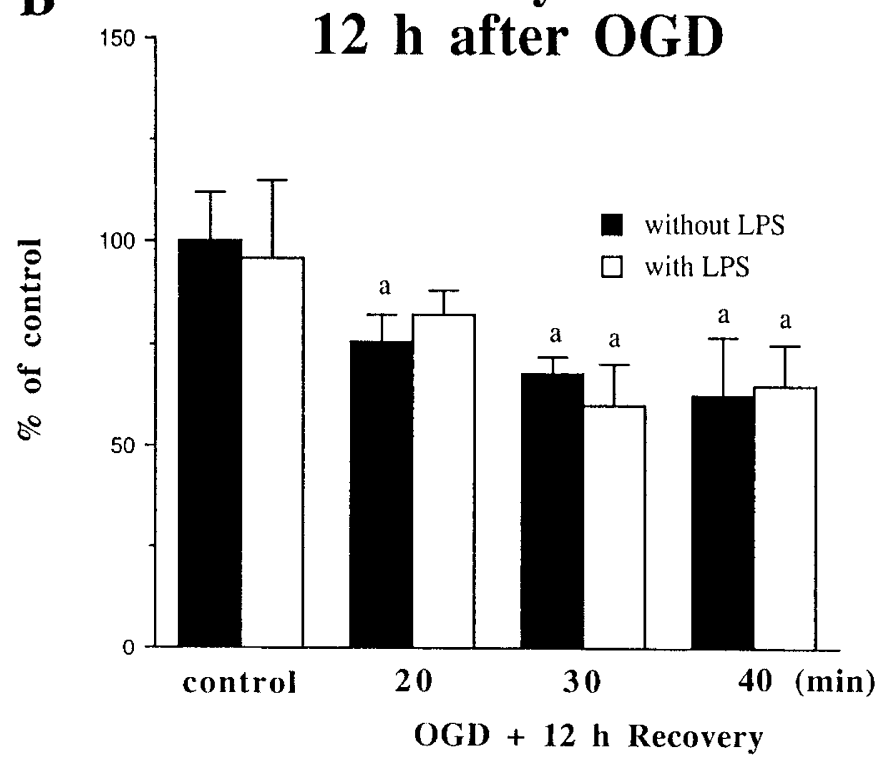

Figure 3. Concentration of ATP $(A)$ and rate of protein synthesis $(B)$ in hippocampal tissue slices $12 \mathrm{~h}$ after application of LPS and OGD. OGD lasted 20-40 min. A set of these tissue slices was incubated in LPS (4 mg/L) for $2 \mathrm{~h}$ before, during, and $12 \mathrm{~h}$ after OGD. The ATP concentration in controls was $16.4 \pm 3.2 \mathrm{nmol} / \mathrm{mg}$ protein (without LPS) and $15.0 \pm 3.1 \mathrm{nmol} / \mathrm{mg}$ protein (with LPS). Protein synthesis in controls amounted to $181 \pm 22 \mathrm{dpm} / \mu \mathrm{g}$ protein per $30 \mathrm{~min}$ (without LPS) and $173 \pm 34 \mathrm{dpm} / \mu \mathrm{g}$ protein per $30 \mathrm{~min}$ (with LPS). Values are given as mean \pm SD. The statistical significance of differences within and between groups was assessed by ANOVA and the Scheffé post hoc test. a, $p<0.05$ (OGD $v s$ controls). Significant differences between groups could not be detected.

activated by this procedure (Fig. $2 A$ ). This seems to contradict some in vitro (18) and in vivo (19) studies on adult animals in which an increase in cerebral NO release was measured after stimulation with LPS. However, because the LPS signal cascade depends on the expression of various membrane-bound receptors, e.g. CD14, TLR2/4 (20, 21), this discrepancy may possibly arise from ontogenetic differences in the maturation of
Table 1. Total adenylate pool and AEC $12 \mathrm{~h}$ after $O G D$ and application of LPS

\begin{tabular}{lccccc}
\hline & \multicolumn{2}{c}{ TAN } & & \multicolumn{2}{c}{ AEC } \\
\cline { 2 - 3 } \cline { 5 - 6 } \multicolumn{1}{c}{ Time } & Without & With LPS & & Without & With LPS \\
$(4 \mathrm{mg} / \mathrm{L})$ & & LPS & $(4 \mathrm{mg} / \mathrm{L})$ \\
\hline Control & $100 \pm 19$ & $92 \pm 19$ & & $100 \pm 1$ & $100 \pm 11$ \\
OGD 20 min & $77 \pm 10^{*}$ & $85 \pm 13$ & & $97 \pm 1$ & $98 \pm 1$ \\
OGD 30 min & $55 \pm 3^{*}$ & $54 \pm 14^{*}$ & & $96 \pm 3^{*}$ & $94 \pm 2^{*}$ \\
OGD 40 min & $38 \pm 6^{*}$ & $53 \pm 10^{*} \dagger$ & & $95 \pm 1^{*}$ & $95 \pm 1^{*}$ \\
\hline
\end{tabular}

Values are given as percent of control (mean $\pm \mathrm{SD})$. The absolute values of total adenylate pool (TAN) in the control groups were $17.9 \pm 3.5 \mathrm{nmol} / \mathrm{mg}$ protein (without LPS) and $16.5 \pm 3.4 \mathrm{nmol} / \mathrm{mg}$ protein (with LPS), and those of AEC were $0.94 \pm 0.01$ (without LPS) and $0.94 \pm 0.00$ (with LPS), respectively. OGD lasted between 20 and $40 \mathrm{~min}$. Statistically significant differences within and between groups were assessed by ANOVA and the Scheffé post hoc test. $* p<0.05$ (OGD $v s$ control); $\uparrow p<0.05$ (LPS $v s$ without LPS).

these proteins that link LPS stimulus to the activation of NO synthase. One might speculate that the application of LPS together with interferon- $\gamma$ would have been more effective in stimulating NO synthase (22). However, as demonstrated in a variety of studies, $\mathrm{NO}$ production can easily be induced by sole application of LPS $(18,19,23,24)$. Thus, the presence of interferon- $\gamma$ is not an absolute prerequisite for LPS-mediated NO activation.

In contrast to the effect of adding LPS to the incubation medium, OGD caused a marked rise in cGMP concentrations in fetal tissue slices, and this increase was almost completely inhibited by blocking NO synthase with L-NNA (Fig. 2, $B$ and $C$ ). This implies that NO synthase is activated by OGD in our model, producing significant amounts of NO. However, the activation of NO synthase after OGD was not additionally influenced by LPS. NO does not therefore seem to play a major role in mediating direct toxic effects of LPS on fetal brain tissue.

The effect of LPS on metabolic disturbances of hippocampal slices after prolonged periods of OGD was investigated by measuring tissue concentrations of high-energy phosphates and protein synthesis. Incubating hippocampal slices in aCSF containing LPS modulated neither ATP tissue concentrations nor rates of protein synthesis (Fig. 3). Nor did this treatment modify changes in adenylate concentrations or the AEC (Table 1). In vulnerable brain areas such as the hippocampal CA1 subfield, protein synthesis is already markedly suppressed shortly after ischemia, i.e. before cell damage is morphologically manifested. Prolonged inhibition of protein synthesis can therefore be viewed as a sensitive early marker of ischemic cell injury, and this is probably also true for LPS-mediated damage of neuronal tissue (7). Furthermore, cells cannot survive if their energy metabolism is severely disturbed. Although the indicators used in our experiments have sufficient power to detect damaging effects on hippocampal slices, we cannot exclude the possibility that LPS may injure neuronal tissue via delayed activation of pathways that are involved in apoptotic cell death. However, inasmuch as intraperitoneal injection of LPS at a dosage of $4 \mathrm{mg} / \mathrm{kg}$ kills newborn guinea pigs within $6 \mathrm{~h}$, such mechanisms seem to be of minor importance in the present study. Nevertheless, delayed cell injury may explain some 
discrepancies between our results and studies in adult animals and completely differentiated cell cultures in which LPSinduced injury was observed (25-30). In addition, if LPS is exclusively toxic to a certain cell type, e.g. oligodendrocyte progenitors, and the portion of this cell type contributing to total energy metabolism and protein synthesis is very small, possible deleterious effects of LPS on hippocampal slices may have been overlooked. However, inasmuch as clinical observations have shown that bacterial infection of the immature brain not only induces white matter but also cortical injury (31), a differentiation between cell type-specific lesions was not the main question of the present paper. A further reason why some experiments in adult animals and fully differentiated cell cultures revealed toxic effects of LPS on neuronal cells that were not found in the present study may be that LPS did not stimulate NO production in fetal hippocampal slices owing to ontogenetic differences in the maturation of proteins that link LPS stimulus to the activation of NO synthase. Because NO as a radical can substantially damage neuronal tissue, this discrepancy would seem to be of biologic importance.

Despite the fact that the dose of LPS used in the present study killed newborn guinea pigs within $6 \mathrm{~h}$, but did not have any effect on protein synthesis and energy metabolism, one might argue that increasing the LPS concentration would still have a direct toxic effect on fetal hippocampal slices. However, even doubling the LPS dose failed to affect the recovery of ATP tissue concentrations and protein synthesis in the slices $12 \mathrm{~h}$ after OGD lasting between 20 and $40 \mathrm{~min}$ (data not shown). Furthermore, the lack of any effect of LPS on cell metabolism in the present study is unlikely to result from species differences, because the pathways by which LPS activates various cellular mechanisms are ubiquitous and probably highly preserved in the genome of mammals. Differences in electrical activity between neurons in the slice and in the brain that might explain discrepancies in cellular activation after application of LPS are not very likely, because the fetal brain consumes much less energy than the adult owing to a lack of environmental stimuli (32).

From the present study, we conclude that, apart from their influence on the cardiovascular system, LPS do not alter metabolic disturbances in hippocampal slices of fetal guinea pigs $12 \mathrm{~h}$ after OGD. A direct toxic effect of LPS on immature brain tissue within this interval does not therefore seem very likely. However, delayed activation of LPS-sensitive pathways that may be involved in cell death, or damage limited to a small subgroup of cells such as oligodendrocyte progenitors, cannot be fully excluded.

Acknowledgments. The authors thank Stefan Reininghaus und Margret Schulte-Spechtel for their excellent technical assistance.

\section{REFERENCES}

1. Dammann O, Leviton A 1997 Maternal intrauterine infection, cytokines, and brain damage in the preterm infant. Pediatr Res 42:1-8

2. Yoon BH, Romero R, Kim CJ, Jun JK, Gomez R, Choi JH, Syn HC 1995 Amniotic fluid interleukin-6: a sensitive test for antenatal diagnosis of acute inflammatory lesions of preterm placenta and prediction of perinatal morbidity. Am J Obstet Gynecol 172:960-970
3. Zupan V, Gonzalez P, Lacaze-Masmonteil T, Boithias C, D'Allest AM, Dehan M, Gabilan JC 1996 Periventricular leukomalacia: risk factors revisited. Dev Med Child Neurol 38:1061-1067

4. Garnie Y, Coumans A, Berger R, Jenson A, Hasaarft (2000) Circulatory changes during endotoxemia may contribute to fetal brain damage in preterm sheep. J Soc Gynecol Invest 7:69

5. Berger R, Djuricic B, Jensen A, Hossmann KA, Paschen W 1996 Ontogenetic differences in energy metabolism and inhibition of protein synthesis in hippocampal slices during in vitro ischemia and $24 \mathrm{~h}$ of recovery. Dev Brain Res 91:281-291

6. Berger R, Jensen A, Paschen W 1998 Metabolic disturbances in hippocampal slices of fetal guinea pigs during and after oxygen-glucose deprivation: is nitric oxide involved? Neurosci Lett 245:163-166

7. Hossmann KA, Widmann R, Wiessner Ch, Dux E, Djuricic B, Röhn G 1992 Protein synthesis after global ischemia and selective vulnerability. In: Krieglstein J, Oberpichler-Schwenk H (eds) Pharmacology of Cerebral Ischemia. Wissenschaftliche Verlagsgesellschaft mbH, Stuttgart, pp 289-299

8. Djuricic B, Berger R, Paschen W 1994 Protein synthesis and energy metabolism in hippocampal slices during extended ( 24 hours) recovery following different periods of ischemia. Metab Brain Dis 9:377-389

9. Decking UKM, Flesche CW, Gödecke A, Schrader J 1995 Endotoxin-induced contractile dysfunction in guinea pig hearts is not mediated by nitric oxide. Am J Physiol 268:H2460-H2465

10. Saito K, Suyama K, Nishida K, Sei Y, Basile AS 1996 Early increases in TNF- $\alpha$, IL-6 and IL-1 $\beta$ levels following transient cerebral ischemia in gerbil brain. Neurosci Lett 206:149-152

11. Paschen W 1995 Comparison of biochemical disturbances in hippocampal slices of gerbil and rat during and after in vitro ischemia. Neurosci Lett 199:41-44

12. Atkinson DE 1968 The energy charge of the adenylate pool as a regulatory parameter: interaction with feedback modifiers. Biochemistry 7:4030-4034

13. Lowry OH, Rosenbrough NJ, Farr AL, Randall R 1951 Protein measurement with the Folin phenol reagent. J Biol Chem 193:265-275

14. Murphy DJ, Sellers S, MacKenzie IZ, Yudkin PL, Johnson AM Case-control study of antenatal and intrapartum risk factors for cerebral palsy in very preterm singleton babies. Lancet 346:1449-1454

15. Meltzer JC, Sanders V, Grimm PC, Stern E, Rivier C, Lee S, Rennie SL, Gietz RD, Hole AK, Watson PH, Greenberg AH, Nance DM 1998 Production of digoxigeninlabelled RNA probes and the detection of cytokine mRNA in rat spleen and brain by in situ hybridization. Brain Res Brain Res Protoc 2:339-351

16. Benigni F, Villa P, Demitri MT, Sacco S, Sipe JD, Lagunowich L, Panayotatos N, Ghezzi P 1995 Ciliary neurotrophic factor inhibits brain and peripheral tumor necrosis factor production and, when coadministered with its soluble receptor, protects mice from lipopolysaccharide toxicity. Mol Med 5:568-575

17. Di Santo E, Adami M, Bertorelli R, Ghezzi P 1997 Systemic interleukin 10 administration inhibits brain tumor necrosis factor production in mice. Eur $\mathrm{J}$ Pharmacol 336:197-202

18. Simmons ML, Murphy S 1992 Induction of nitric oxide synthase in glial cells. J Neurochem 59:897-905

19. Wong ML, Rettori V, Al-Shekhlee A, Bongiorno PB, Canteros G, McCann SM, Gold PW, Licino J 1996 Inducible nitric oxide synthase gene expression in the brain during systemic inflammation. Nat Med 2:581-584

20. Ulevitch RJ, Tobias PS 1995 Receptor-dependent mechanisms of cell stimulation by bacterial endotoxin. Annu Rev Immunol 13:437-457

21. Ulevitch RJ 1999 Endotoxin opens the tollgates to innate immunity. Nat Med 5:144-145

22. Kim H, Lee E, Shin T, Chung C, An N 1998 Inhibition of the induction of the inducible nitric oxide synthase in murine brain microglial cells by sodium salicylate. Immunology 95:389-394

23. Pahan K, Sheikh FG, Namboodiri AM, Singh I 1998 Inhibitors of protein phosphatase 1 and $2 \mathrm{~A}$ differentially regulate the expression of inducible nitric-oxide synthase in rat astrocytes and macrophages. J Biol Chem 273:12219-12226

24. Chen CC, Wang JK, Chen WC, Lin SB 1998 Protein kinase C eta mediates lipopolysaccharide-induced nitric-oxide synthase expression in primary astrocytes. J Biol Chem 273:19424-19430

25. Luthman J, Radesater AC, Oberg C 1998 Effects of the 3-hydroxyanthranilic acid analogue NCR-631 on anoxia-, IL-1beta- and LPS-induced hippocampal pyramidal cell loss in vitro. Amino Acids 14:263-269

26. Matsuoka Y, Kitamura Y, Takahashi H, Tooyama I, Kimura H, Gebicke-Haerter PJ, Nomura Y, Taniguchi T 1999 Interferon-gamma plus lipopolysaccharide induction of delayed neuronal apoptosis in rat hippocampus. Neurochem Int 34:91-99

27. Kim YS, Kennedy S, Tauber MG 1995 Toxicity of Streptococcus pneumoniae in neurons, astrocytes, and microglia in vitro. J Infect Dis 171:1363-1368

28. Jeohn GH, Kong LY, Wilson B, Hudson P, Hong JS 1998 Synergistic neurotoxic effects of combined treatments with cytokines in murine mixed neuron/glia cultures. J Neuroimmunol 85:1-10

29. Kong LY, Maderdrut JL, Jeohn GH, Hong JS 1999 Reduction of lipopolysaccharideinduced neurotoxicity in mixed cortical neuron/glia cultures by femtomolar concentrations of pituitary adenylate cyclase-activating polypeptide. Neuroscience 91:493500

30. Szczepanik AM, Fishkin RJ, Rush DK, Wilmot CA 1996 Effects of chronic intrahippocampal infusion of lipopolysaccharide in the rat. Neuroscience 70:57-65

31. Volpe JJ 1995 Neurology of the Newborn. WB Saunders, Philadelphia, pp 730-769

32. Berger R, Gjedde A, Heck J, Müller E, Krieglstein J, Jensen A 1994 Extension of the 2-deoxyglucose method to the fetus in utero: theory and normal values for the cerebral glucose consumption in fetal guinea pigs. J Neurochem 63:271-279 